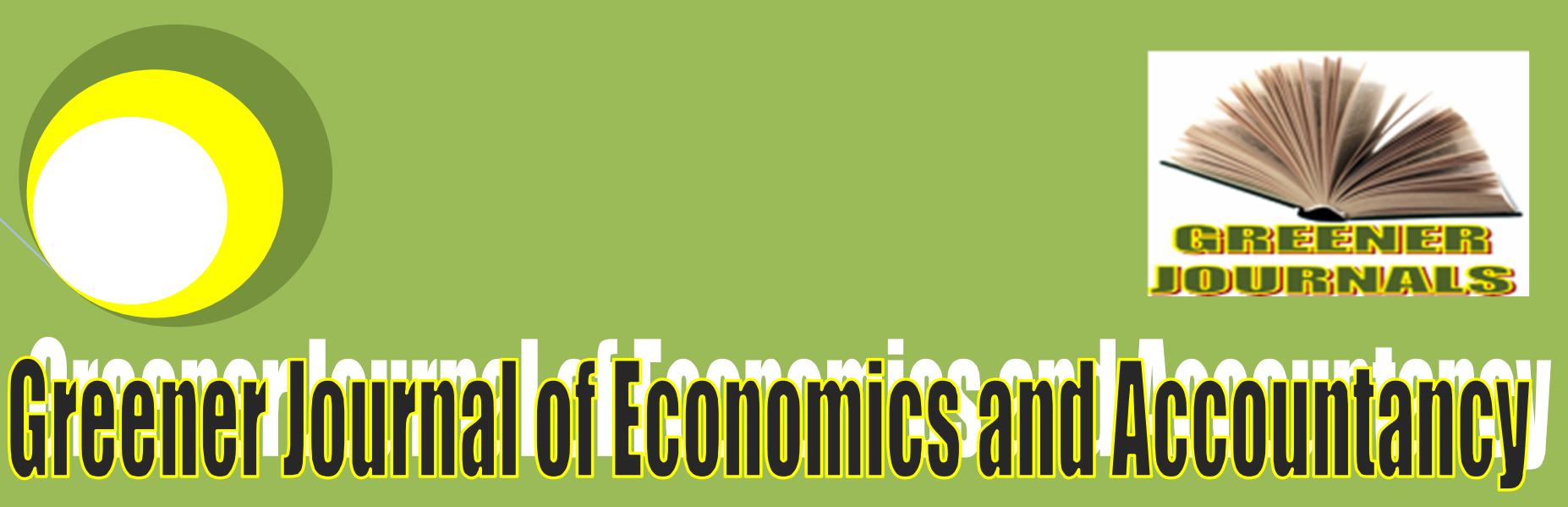

ISSN: 2354-2357

Submitted: 20/11/2017

Accepted: 22/11/2017

Published: 29/11/2017

Does Fiscal Deficit Stimulate Employment? Evidence from Nigeria's Experience: VAR Approach

By

Nwaeze Nnamdi Chinwendu Kalu Ijeoma Eme Tamuno Steve Otonye 
Research Article (DOI: http://doi.org/10.15580/GJEA.2017.3.112017169)

\title{
Does Fiscal Deficit Stimulate Employment? Evidence from Nigeria's Experience: VAR Approach
}

\section{${ }^{* 1}$ Nwaeze Nnamdi Chinwendu, ${ }^{2}$ Kalu ljeoma Eme, ${ }^{3}$ Tamuno Steve Otonye}

\author{
${ }^{1}$ Dept. of Economics, University of Port Harcourt. \\ ${ }^{2}$ Dept. of Economics, University of Port Harcourt. \\ ${ }^{3}$ Department of Economics, University of Port Harcourt. \\ jiekal@ yahoo. com; Tel: ${ }^{2}+2348033098733 ;{ }^{3}+2348034725830$ \\ *Corresponding Author's Email: nwaezennamdi @yahoo. com, Tel: +2348093063220
}

\begin{abstract}
This study investigated the relationships between fiscal deficit, financing options vis-a-viz domestic and external borrowing financed deficits and unemployment rate in Nigeria. The study adopted the vector autoregression (VAR) econometric technique to analyze the time series data obtained from the Central Bank of Nigeria and other sources. The study found long run relationship between unemployment and the other endogenous variables, namely; GDP per capita, overall fiscal deficit, domestic credit to the private sector, domestic borrowing financed deficit, external borrowing financed deficit and foreign direct investment. The study also found positive relationship between unemployment rate and fiscal deficits. However, the variation in unemployment is mainly from overall fiscal deficit financed through domestic borrowing. The study concluded that, fiscal deficits especially when financed through domestic borrowing components, have contributed in fuelling worsening unemployment problem in Nigeria. This is found to be empirically true as mounting public debt burden pose an obstacle to initiating new critical development projects that could generate employment. The study recommends that the rising trend of using domestic sources to finance fiscal deficit should be moderated and discouraged. If borrowing is absolutely necessary, external borrowing should be a better alternative. In the stead of public borrowing, fiscal managers should also undertake holistic tax reforms to improve tax revenue and use same to fund government expenditure expansions, especially new critical capital projects with positive linkages.
\end{abstract}

Keywords: fiscal deficit, unemployment, aggregate demand, employment stimulation and crowding out

\section{INTRODUCTION}

The Keynesian theory of employment, output and income as propounded by Keynes (1936), was a theory developed out of necessity to ameliorate the Great Depression of the 1930s in the United States, which rattled the classical theorists whose prescriptions fell to stimulate the economic unto the path of recovery, prior to Keynes intervention. Owing to the efficacy of Keynes theory which hitherto ended the depression, modern development theorists especially the Keynesian and Neo- Keynesian theorists now favour the unbalancing of government fiscal budget owing to its acclaimed expansionary effects on economic growth and development. To the proponents, for economic growth and development to be achieved, a country especially the less developed nations who most a times lack adequate savings and capital formation; high poverty and unemployment level, dearth of critical infrastructures; as well as the private sector's lack of desired capacity to drive growth and industrialization, needs government intervention in the form of expansionary fiscal policy to raise savings and capital formation, improve critical infrastructures, develop the productive capacity of the economy; invest in functional education, research and development and healthcare to improve human capital development while maintaining macroeconomic stability in price level and exchange rates in the economy.

According to Mohanty (2012), fiscal deficits are most desirable in an economy faced with deficiencies in aggregate demand or an economy experiencing recession or depression as the case may be. This is because prolonged fiscal deficit regimes may reverse the employment and growth expansion targeting, especially in the longer terms. These reversals in macroeconomic objectives of employment and growth stimulation may come in the form of rising inflation, exchange rate volatility, mounting public debt/debt overhang and crowding out of private investment. However, in the case of Nigeria, fiscal deficit has not been used as an interventionist fiscal policy, rather , 
it has become presumably part of the budgetary norm in the country, since Nigeria independence in 1960. It is pertinent to point out here that Nigeria has undertaken sustained fiscal deficits over the years till the present day. For instance, from 1970 to 2016 with the exception of these years: 1971, 1973, 1974, 1979, 1995, \& 1996 where overall fiscal surpluses of \#0.171billion, \#0.166billion, \#1.80billion, \#1.16billion, \#1billion, and \#32.05billion respectively were recorded, Nigeria has had four decades (40 years) of sustained overall fiscal deficits. Whereas overall fiscal deficits were N0.455billion in 1970, it rose to N2.82billion in 1978, N3.6billion, N35.76billion, N221.05billion, N1.158trillion and N1.577trillion in 1981, 1991, 2001, 2011 and 2015 respectively (CBN, 2015).

Consequently, owing to the cardinal role fiscal deficits have assumed in Nigeria's fiscal operations, Nigeria's fiscal domain has been characterized by an extraordinary rate of debt accumulation even in times of unprecedented oil boom and robust foreign reserves. This is unwittingly unconnected to fiscal deficit regimes over the years. Given that fiscal deficits in Nigeria are chiefly financed through borrowing, it has resulted into the country carrying an over blotted debt burden both in terms of principal and interest servicing. For instance, Nigeria's total government debt grew from N13.526 billion in 1981 to N69.892 billion in 1986 and increased further to N960.994 billion in 1996. The increasing trend was significantly sustained between 1998 and 2004 as total government debt increased to N1.170 trillion in 1998, N3.995 trillion and N6.260 trillion in 2000 and 2004 respectively. The value of government debt dropped to N4.220 trillion in 2005 and further declined to N2.204 trillion in 2006 mainly as a result of the debt forgiveness granted to Nigeria by the Paris Club consortium in 2005. However, total debt outstanding resumed its incremental trajectory afterwards as government total debt stood at N3.818 trillion, N7.554 trillion, N12.604 trillion and N17.360 trillion in 2009, 2012, 2015 and 2016 respectively(DMO, various) and (Nwankwo, 2017).

As observed by Saleh (2003) the relationship between fiscal deficits and macroeconomic variables such as; employment, economic growth, interest rates, trade deficit, exchange rate, inflation among others represents one of the most extensively debated topics among economists and policy makers in both developed and developing countries. As captured by Tobin (1982) while writing about the macroeconomic impact of fiscal deficit: "Few issues of economic theory and fact evoke such polar disagreement. The contesting views carry relatively divergent implications for public fiscal and financial policy". In furtherance to these narratives therefore, it becomes imperative for further studies to be undertaken to investigate fiscal deficits and its ability to solve the unemployment problem, especially in developing countries like Nigeria. As a country, do we continue to hold fast to the views of the Keynesian economists that fiscal deficit crowds-in private investments and stimulates economic growth and employment through the investment and government multipliers? Or the neoclassical view that it crowds-out private investment through its negative impact on interest rate and other macroeconomic variables vis-a-viz inflation and exchange rate (macroeconomic instability)? On the other hand, the Ricardian equivalent suggests neutrality of fiscal deficits on aggregate demand, employment and output. Despite these controversies, this debate remains inconclusive and will continue to rekindle interests in policy issues. In a nutshell, the unabated controversy demands further investigations on the relationship between fiscal deficits; fiscal deficit financing options and macroeconomic performance in Nigeria. Thus, at what cost is the growth and employment stimulation objectives of fiscal deficit is to the Nigerian economy in terms of macroeconomic stability? This present work is an attempt to resolve the mounting controversy and to add empirical evidence on what the state of things is in the Nigerian economy, with regards to fiscal deficits and macroeconomic performance. The aim of this study is to investigate the relationships between fiscal deficits; financing options vis-a-viz domestic and external borrowing and unemployment in Nigeria. The specific objective is to determine the effect of fiscal deficit and the disaggregated effects of domestic and external borrowing financed fiscal deficit on unemployment in Nigeria.

\subsection{LITERATURE REVIEW}

\subsection{Review of Theoretical Literature}

The economic essential of fiscal policy is to effect a countercyclical policy so that booms and depressions during the course of business cycles are counterbalanced. By this therefore we mean that fiscal policy is fundamentally used in fine-tuning the economy, this is why Keynes (1936) advocated budget deficit (an injection into the economy to stimulate aggregate demand) to effect a transition from mass unemployment to near full employment. The theoretical framework of this research work therefore, is based on Keynes theory of employment which gave utmost relevance to fiscal policy and government consumption. However, the criticisms of this postulation and the corresponding versions as presented by the Classical and the neoclassical economists as well as the Ricardian equivalence shall also be reviewed. 


\subsubsection{Keynes Employment, Output and Income Theory.}

This theory was postulated following the American depression of the 1930s in which John Maynard Keynes attributed the prevailing depression and unemployment to the problem of under-spending or under-consumption. In the Keynesian theory of employment, public spending therefore, can contribute positively to stimulating economic growth. An increase in government consumption is likely to lead to an increase in employment, profitability and investment through the multiplier effects on aggregate consumption. As a result government spending augments the aggregate demand, which triggers an increased output depending on expenditure multipliers. Keynes, therefore, encouraged the running of budget deficits by increasing government spending and/or reducing taxes, and by so doing cited that the market solution would be ineffective because the price mechanism and wages that have to respond to the existence of unemployment do not adjust with sufficient speed (Oluba, 2008). To Keynes, the economy is inherently unstable and needs to be steadied through vigorous government intervention and/or appropriate policies of government. Deficit financing to the Keynesians is as an important tool to achieve a desired level of aggregate demand consistent with full employment. The major assumption of this theory is that the economy is working at less than full employment level of national income. Given the existence of output gap in the economy, increase in debt financed government expenditure will bring expansion in output and income. Thus, they argue that an escalation in government spending through the use of borrowed money cause an upward shift on the aggregate demand curve. By implication therefore, deficit financing according to the Keynesian theory can be used to create additional employment when the economy is suffering from a deficiency of effective demand. As an instrument of recovery after recession, deficit financing can be used to mitigate against severe cyclical fluctuations (Dewett, 2009).

Keynesian postulation on the efficacy of fiscal deficit being able to stimulate employment and economic growth is premised on his multiplier concept. If the assumption of the existence of unutilized human and material resources in terms of economic recessions holds therefore, an increase in government spending (or tax reduction) over its revenue will increase both investment and consumption hence leading to expansion of output in multiples of the government expenditure, which Keynes christened the government expenditure multiplier. However, the magnitude of the output expansion is a function of the marginal propensity to consume (MPC) in the economy. Summarily therefore, government spending increases total output more rapidly in an economy with high MPC than country with low MPC (Ali and Ahmad 2014).

The above theory however was strongly opposed by the classical and neoclassical schools. The classical school criticism postulate that fiscal deficits incessantly financed by domestic debt crowds out investment and by extension lower the level of economic growth. In sum, they postulate that excessive fiscal deficits lead to poor economic performance. Thus, fiscal deficits financed by public debts are principally counterbalance by the crowding out effect of deficit financing on private sector investment, and this by extension lowers the level of economic growth. The implication of such policy does not stop at the crowding out effect on private investment, also the society will have to bear the burden of increased public debts as a result of debt financed expansion in government expenditure. This overriding objection of Keynes employment theory as well as the efficacy of fiscal deficit in stimulating economic growth by the classical economists was premised on their assumption that the economy always operates at full employment. If an economy is already operating at full employment, any extra expenditure financed by debt or by money creation is bound to create inflationary rise in prices (Anyanwu, 1995; Dewett, 2009). On their part, the neoclassical economists collaborated the position of the classical economists that fiscal deficit would have adverse effect on economic growth. Their argument is that fiscal deficit is an obvious weakening of government savings. If government savings are weakened, it will put pressure on rate of interest except if it is fully offset by private savings. Therefore, a decline in national savings will exert pressure on cost of credit (interest rate) which crowds out private investment and a resultant fall in general level of output in the long-run. The neoclassical economists further argued that the manner in which the deficit is financed is capable of influencing the level of consumption and investment and by extension economic growth (Omitogun and Tajudeen, 2007; (Mohanty, 2012).

Conclusively, the contribution of the Ricardian equivalent theory is that of a neutrality effect of fiscal deficit on economic growth. The theory is premised on the assumption that individuals maintain permanent consumption pattern over their life-time. If this assumption holds, it therefore follow that any excess of government expenditure over revenue enjoyed by the public today must be paid in form of tax in the near future. By this, expansionary budget will not have effect on the present individuals' consumption, as they will rather save against the tax burden to be paid in the future. In the case of investment, expansionary budget which infers reduction in government savings may be fully offset by the private savings as such having no effect on cost of credit thereby having an indifferent effect on investment. To the Ricardian equivalent theory summarily, fiscal deficits will neither affect real interest rate to crowd out investment nor stimulates consumption to expand output. Therefore fiscal deficit is a useful stabilization technique to smoothen the impact of revenue shocks or for meeting the requirements of lumpy expenditures (Mohanty, 2012). 


\subsection{Review of Empirical Literature}

Several studies have been conducted to determine the relationship between fiscal deficits and unemployment and/or employment. The work of Michele (2005) evaluated the dynamic effects of fiscal policy shocks on government employment in the U.S economy. His findings show negative impulse for private output and a positive impulse for government output as a result of a shock in government employment, given that output is reallocated from private to government sector. His findings also reveal that fiscal shock lead to a negative and significant impulse on wealth; household reduce consumption and increase labour supply if government consumption expenditure consists solely of purchase of final goods. The work of Antonio and llian (1998) examined the dynamic effects of fiscal policy on macroeconomic variables, using the VAR methodology. Their findings reveal positive innovations in government spending to be followed by strong and persistent increases in consumption and employment. Kalle's study in 2007 used a panel data analysis involving 52 countries for the period 1971 to 1980 , to investigate the effect of fiscal policy on economic growth both in the short run and long run. The findings of the study shows that the Keynesian principles do not hold given that fiscal policy cannot have significant impact on the economy in the short run; however, in the long run, fiscal policy was found to have positive effect in the long run. His conclusion was that expansionary fiscal policy is not beneficial to the economy at all.

The study of Arewa and Nwakahma (2013) studied the relationship between government expenditures and a set of macroeconomic variables namely; Gross Domestic Product, consumer price index and unemployment for the period of 1981 to 2011. The study adopts Johansson multivariate co-integration for its appraisal and found that there is long-run relationship between government expenditure and the specified macroeconomic variables. Also, the study found that an increase in capital expenditure improves economic growth, while recurrent expenditure is detrimental to growth. Austin and Ogbole (2014) investigated public sector spending and macroeconomic variables in Nigeria for a period of 1970 to 2010. Their study conducted a test of causal relationships between government expenditure (GE) and other explanatory variables namely; Gross Domestic Product (GDP), unemployment (UER), inflation (IFR) and Balance of Payments (BOP) using Ordinary Least Squares, Johansson's co-integration and Granger causality tests. The results of the investigation shows that public sector was more effective though marginally in stimulating economic growth in the period of regulation and more effective in reducing unemployment and enhancing Balance of Payments in the period of regulation. With respect to maintaining price stability, the public sector was significantly more effective in the period of deregulation. Finally, the Granger causality test shows causal flow from government expenditure (GE) to Balance of Payments; no causal flows to Gross Domestic Product, inflation rate (IFR) and unemployment (UER) in Nigeria. In his study, Obayori (2016) examined the effect of fiscal policy on unemployment in Nigeria, using the error correlation method. His findings revealed that both capital and recurrent expenditure of government have negative effect on unemployment in Nigeria.

\subsection{METHODS OF STUDY}

This section presents the method(s) of study that was adopted in investigating fiscal deficits and macroeconomic performance in Nigeria. It encompasses down the research design, model specifications, data collection method and sources as well as the techniques of data analysis.

\subsection{Research Design}

The study is mainly a quantitative research and adopted this design because it is an empirical study of the relationships and/or interactions between fiscal deficits; financing options vis-a-viz domestic and external borrowing and unemployment in Nigeria. The econometric modeling technique of Vector Autoregression (VAR) was adopted as the main analytical tool.

\subsection{Model Specification}

\subsubsection{The Variables in the Model.}

1). Economic Growth is defined here as the expansion in national output measured by growth in Gross Domestic Product (GDP). Economic growth is proxied by real GDP per Capita. We elected to use real GDP Per Capita in order to ascertain if increases in nominal GPD have been accompanied with improvements in social welfare, vis-a-viz declining poverty and income inequality among others. This is because GDP per Capita is a better measure of welfare and or improvements in general living standard of the population. 
2). Domestic Credit to the Private Sector measures growth rate of bank credits to the private sector in Nigeria. This is an important component of the economy as it provides an indicator of the future productive capacity of the economy as well as capital formation. For economic growth and development to be achieved and sustained, private sector participation is imperative.

3). Unemployment Rate is a measure of the prevalence of unemployment in an economy. It is calculated in percentage by dividing the number of unemployed individuals by all individuals currently in the labour force.

4). Fiscal Deficits defines the overall or accumulated shortfall of government revenues over government expenditures. Thus the overall gap between government expenditure and government revenue in a given period was used as fiscal deficits. The overall fiscal deficits figure which represents accumulated deficits or surpluses of the Federal Government of Nigeria overtime will be used for this variable. Overall fiscal deficits are chiefly financed by two broad classifications; Domestic and External Borrowings.

5). Domestic Borrowing Financed Deficit represents the size of overall fiscal deficit that is financed by domestic borrowing.

6). External Borrowing Financed Deficit represents the size of overall fiscal deficit that is financed by external borrowing.

7). Foreign Direct Investment is an investment made by individual or a company from other countries in Nigeria in business interests, in the form of either establishing a business operations or acquiring business assets in Nigeria, such as ownership or controlling interest in a Nigerian company.

\subsubsection{Analytical Framework}

This study is aim at examining empirically the relationships between fiscal deficits; financing options vis-a-viz domestic and external borrowing and unemployment in Nigeria. This study adopted the Vector Autoregressive (VAR) model. The vector autoregressive (VAR) model is a theoretical modeling technique used in economic analysis. It is one of the most successful, flexible, and easy to use models for the analysis of multivariate time series. It is a natural extension of the univariate autoregressive model to dynamic multivariate time series. This study adapted the model specified by (Sims 1980).

A VAR is system in which every equation has the same right hand variable, and those variables include lagged values of all of the endogenous variables. VARs are useful for forecasting systems of interrelated time series variables. VARs are also used for analyzing the dynamic impact of different types of random disturbances on systems of variables. The VAR approach sidesteps the need for structural modeling by treating every variable as endogenous variable in the system as a function of the lagged values of all the endogenous variables in the system. The mathematical representation of a VAR is stated as follows:

$y_{t}=A_{1} y_{t-1}+O+A_{p} y_{t-1}+B x_{t}+e_{t}$

Where $y_{t}$ is a $K$ vector of endogenous variables, $x_{t}$ is a $d$ vector of exogenous variables, $A_{1}, A_{p}$, and $B$ are matrices of coefficients to be estimated, and $e_{t}$ is a vector innovations that may be contemporaneously correlated but are uncorrelated with their own lagged values and uncorrelated with all of the right-hand side variables.

Since this study examines the relationships between fiscal deficits; financing options vis-a-viz domestic and external borrowing and macroeconomic performance in Nigeria. Some of the macroeconomic performance or indicators adopted to form our model in this study are as follows:

Vector Autoregressive (VAR) model with the variables stated in their lagged values as follows:

\section{Unemployment Model:}

This model is built to estimate the effect of overall fiscal deficits; domestic and external borrowing financed deficit shocks on unemployment rate in Nigeria. The endogenous variables included in the model are specified thus:

(UNEP, GDPP, OFDE, DBFD, EBFD, FDI, DCPS)

The Vector Autoregressive (VAR) transformation of model four (equation 3.2) is stated as: 


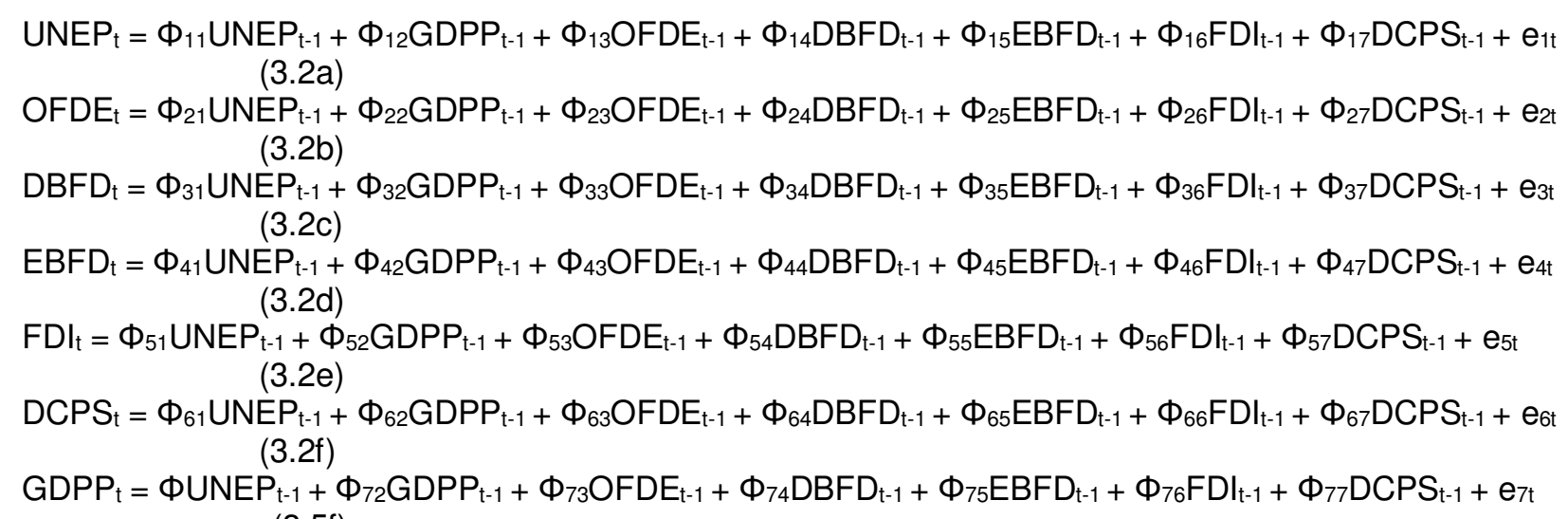

Where;

GDPP = GDP Per Capita

$\mathrm{OFDE}=$ Overall fiscal deficits

DBFD $=$ Size of overall fiscal deficits financed by domestic borrowing

$\mathrm{EBFD}=$ Size of overall fiscal deficits financed by external borrowing

DCPS $=$ Growth rate of domestic credit to the private sector

$\mathrm{UNEP}=$ unemployment rate

$\mathrm{FDI}=$ foreign direct investment

\subsection{Data Analysis Technique}

This study relies on the descriptive statistics as well as Vector Autoregressive model (VAR) approach as the main analytical tools to analyze the effects of fiscal deficits on macroeconomic performance in Nigeria. In order to achieve this, the unit root model test, co-integration as well as Vector Autoregressive model (VAR) approaches were used to model the relationships between fiscal deficits; financing options vis-a-viz domestic and external borrowing and macroeconomic performance in Nigeria.

\subsubsection{Descriptive Statistics}

One of the methods researchers normally use to investigate the cause-effect relationship between variables is through descriptive statistics. Descriptive statistics is that type of statistics that involves organizing, summarizing and presenting data in a meaningful form or usable format. Thus, in this research simple averages (i.e. mean), kurtosis, Jarque-Bera, and more were employed to analyze the trends of the variables used in this study between 1970 and 2016.

\subsubsection{Unit Root Test}

It is now a common practice to examine the time series properties of economic data as a guide to a subsequent multivariate modeling and inference. If we discover that the variables are integrated of order greater than or equal to one, then it could be the case that these variables are co-integrated. Hence, the study employed the Augmented Dickey-fuller test (ADF) to test for the stationarity of the variables both at level and at difference. Thus, the model is stated as follows:

$\mathrm{y}_{\mathrm{t}}=\mu+\mathrm{P}_{\mathrm{yt}}-1+\varepsilon t$

Where $\mu$ and $\mathrm{P}$ are parameters and $\varepsilon t$ is assumed to be white noise, $\mathrm{y}$ is a stationary series.

If $-1<\mathrm{P}<\mathrm{l}$. if $\mathrm{P}=\mathrm{I}, \mathrm{y}$ is a non-stationary series.

If the process is started at some point, the variance of $y$ increases steadily with time and goes to infinity. If the absolute value of $P$ is greater than one, the series is explosive. Therefore, the hypothesis of a stationarity series can be evaluated by testing whether the absolute value of $P$ is strictly less than one. The simple unit root test described 
above is valid because the series is an AR (I) process. If the series is correlated at higher order lags, the assumption of white noise disturbances is violated.

The Dickey fuller tests take the unit root as the null hypothesis $\mathrm{Ho}: \mathrm{P}=\mathrm{I}$. since explosive series do not make much economic sense, this null hypothesis is tested against the one-sided alternative $\mathrm{HI}: \mathrm{P}<1$. The null hypothesis of a unit root is rejected against the one sided alternative if the t-statistic is less than the critical value.

\subsubsection{Co-integration Tests}

The co-integration deals with the methodology of modeling non-stationary time series variables. According to Maddala (1992) and lyeli (2010) the theory of co-integration explains how to study the interrelationship between the long-run trends in economic variables. Basically, the idea of co-integration rests on the thesis that even though two time series may not themselves be stationary, a linear combination of the two non-stationary time series may be stationary. This study adopts the co-integration to test the existence of a long-term relationship among the variables in the five models.

\subsubsection{Vector Autoregressive (VAR)}

A VAR is system in which every equation has the same right hand variable, and those variables include lagged values of all of the endogenous variables. VARs are useful for forecasting systems of interrelated time series variables. VARs are also used for analyzing the dynamic impact of different types of random disturbances on systems of variables. The VAR approach sidesteps the need for structural modeling by treating every endogenous variable in the system as a function of the lagged values of all the endogenous variables in the system.

It has been pointed out in the literature that individual coefficients from the error-correction model are hard to interpret in the case of vector-autoregressive model. Consequently, the dynamic properties of the five models are analyzed by examining the impulse response functions and the variance decompositions.

\subsubsection{Impulse Response Function}

A shock to a particular variable may not only directly affect the variable but is also transmitted to all of the other endogenous variables. An impulse-response function traces the impact of a one-time shock to one of the innovations on the current and future values of the endogenous variables. The impulse-response, therefore, tells us how macro variables respond to innovations in fiscal deficits. In order words, an impulse-response was applied to trace the reactions of the variables used in this study.

\subsubsection{Forecast Error Variance Decomposition (FEVD)}

While impulse-response functions trace the effects of a shock to one endogenous variable onto the other variables in the VAR, the Variance Decomposition provides information about the relative importance of each random innovation in affecting the random variables in the VAR (Hamilton, 1994). Therefore, Variance Decompositions show the magnitude of the variations in the endogenous variables.

\subsection{RESULT AND DISCUSSIONS}

\subsection{Descriptive Statistics}

Tables 1 below presents the result of the descriptive statistics of the variables employed in the estimations in this study. 
Table 1: Descriptive Statistics Results

\begin{tabular}{|l|l|l|l|l|l|l|l|}
\hline & GDPP & DBFD & EBFD & FDI & DCPS & UNEP & OFDE \\
\hline Mean & 257884. & 1605096 & 928822. & 265619. & 2954173 & 10.2808 & -245079.5 \\
& 8 &. & 9 & 6 &. & 5 & \\
\hline Median & 247876. & 273836. & 451461. & 66787.0 & 127117. & 8.50000 & -15134.70 \\
& 9 & 4 & 7 & 0 & 7 & 0 & \\
\hline Maximum & 383023. & 1105820 & 4890270 & 1360308 & 2108271 & 27.4000 & 202724.7 \\
& 4 & 4 &. &. & 7 & 0 & \\
\hline Minimum & 172402. & 987.300 & 175.000 & 1003.20 & 351.500 & 3.20000 & -2208222. \\
& 7 & 0 & 0 & 0 & 0 & 0 & \\
\hline Std. Dev. & 64846.7 & 2713923 & 1318736 & 401466. & 5739939 & 5.59353 & 490515.4 \\
& 7 &. &. & 5 &. & 8 & \\
\hline Skewness & 0.45179 & 1.94791 & 1.61384 & 1.45888 & 1.94655 & 1.39366 & -2.284982 \\
& 2 & 3 & 4 & 0 & 0 & 6 & \\
\hline Kurtosis & 1.95932 & 5.87591 & 4.47752 & 3.70399 & 5.42526 & 4.51478 & 7.822578 \\
& 9 & 4 & 4 & 5 & 4 & 6 & \\
\hline Jarque- & 3.71978 & 45.9196 & 24.6770 & 17.6424 & 41.1996 & 19.7082 & 86.44441 \\
Bera & 0 & 6 & 6 & 9 & 8 & 7 & \\
\hline Probability & 0.15569 & 0.00000 & 0.00000 & 0.00014 & 0.00000 & 0.00005 & 0.000000 \\
& 0 & 0 & 4 & 8 & 0 & 3 & \\
\hline Sum & 1212058 & 7543950 & 4365467 & 1248412 & $1.39 \mathrm{E}+0$ & 483.200 & -11518735 \\
& 7 & 4 & 7 & 2 & 8 & 0 & \\
\hline Sum & $1.93 \mathrm{E}+1$ & $3.39 \mathrm{E}+1$ & $8.00 \mathrm{E}+1$ & $7.41 \mathrm{E}+1$ & $1.52 \mathrm{E}+1$ & 1439.23 & $1.11 \mathrm{E}+13$ \\
Dev. & 1 & 4 & 3 & 2 & 5 & 3 & \\
\hline Observation & 47 & 47 & 47 & 47 & 47 & 47 & 47 \\
s & & & & & & & \\
\hline
\end{tabular}

Source: Author's Computation (2017)

From tables 1 above, the standard deviation showed that DCPS (5739939.0) was the most volatile variable in the series followed by EBFD (2713923) and DBFD (1318736), while UNEP (5.593538) was the least volatile variable. The skewness statistic showed that GDPP, DCPS, UNEP, DBFD, EBFD and FDI were positively skewed while OFDE variable was negatively skewed. The kurtosis statistic showed that GDPP was platykurtic, suggesting that their distributions were flat relative normal distribution while DCPS, UNEP, OFDE, DBFD, EBFD and FDI was leptokurtic, suggesting that its distribution was peaked relative normal distribution. Based on these observations, it indicates that the series are non-stationary. However, this indication is not surprising since it involves time series data. In sum, there is unit root (non-stationarity) in the series. In such a case, the presence of unit root in the model is further supported by the values of the Jarque-Bera statistic of most of the variables (DCPS, UNEP, OFDE, DBFD, EBFD and FDI) in tables 1 which are above 5.99 (that is, the Jarque-Bera statistic rejects the null hypothesis of normal distribution for all the variables at 5 percent critical value) depicting the presence of unit root.

Based on these observations it is therefore necessary to test for the long run relationship of the series. This we begin by testing for unit root of the series. The unit root test is conducted so as to make the variables stationary. The study adopts the Dickey and Fuller (1979) method called Augmented Dickey Fuller (ADF) unit root tests procedures.

\subsection{Unit Root Test}

Tables 2 and 3 below present the results of the stationarity test for each of the variables used in this study. The Augmented Dickey Fuller (ADF) test was tested with intercept but no trend. 
Table 2: ADF Test Results at Level

\begin{tabular}{|l|l|l|l|l|}
\hline Variables & $\begin{array}{l}\text { ADF test } \\
\text { Statistic }\end{array}$ & $\begin{array}{l}\text { ADF Critical } \\
\text { Value }\end{array}$ & $\begin{array}{l}\text { Level } \\
\text { Significance }\end{array}$ & Remark \\
\hline GDPP & 0.111445 & -2.926622 & $5 \%$ & Non Stationary \\
\hline DCPS & 4.565197 & -2.941145 & $5 \%$ & Non Stationary \\
\hline UNEP & -2.103692 & -2.926622 & $5 \%$ & Non Stationary \\
\hline OFDE & 1.460327 & -2.926622 & $5 \%$ & Non Stationary \\
\hline DBFD & -6.268916 & -2.936942 & $5 \%$ & Stationary \\
\hline EBFD & -2.023845 & -2.928142 & $5 \%$ & Non Stationary \\
\hline FDI & 9.203682 & -2.941145 & $5 \%$ & Non Stationary \\
\hline
\end{tabular}

Source: Author's Computation (2017)

The results of the unit root test in table 2 reveals that only DBFD variable was stationary at level while all the other variables were non stationary at level. We therefore accept the unit root null hypothesis indicating the presence of a unit root at levels and then proceed to employ first differentiation approach to establish the order of integration of the variables using the Augmented Dickey Fuller tests unit root test as presented in the table 3 below.

Table 3: ADF Test Results at $1^{\text {st }}$ Difference

\begin{tabular}{|l|l|l|l|l|l|}
\hline Variables & $\begin{array}{l}\text { ADF test } \\
\text { Statistic }\end{array}$ & $\begin{array}{l}\text { ADF Critical } \\
\text { Value }\end{array}$ & $\begin{array}{l}\text { Level of } \\
\text { Sign } \\
\text { Integration }\end{array}$ & $\begin{array}{l}\text { Order } \\
\text { Remark }\end{array}$ \\
\hline GDPP & -5.956408 & -2.928142 & $5 \%$ & $\mathrm{I}(1)$ & Stationary \\
\hline DCPS & -8.464820 & -2.941145 & $5 \%$ & $\mathrm{I}(1)$ & Stationary \\
\hline UNEP & -6.638054 & -2.928142 & $5 \%$ & $\mathrm{I}(1)$ & Stationary \\
\hline FDI & -4.035462 & -2.928142 & $5 \%$ & $\mathrm{I}(1)$ & Stationary \\
\hline OFDE & -5.965287 & -2.928142 & $5 \%$ & $\mathrm{I}(1)$ & Stationary \\
\hline EBFD & -3.860411 & -2.928142 & $5 \%$ & $\mathrm{I}(1)$ & Stationary \\
\hline
\end{tabular}

Source: Author's Computation (2017)

Tables 3 revealed that GDPP, DCPS, UNEP, OFDE, EBFD and FDI were stationary in their first difference. Hence, the study then concluded that the variables of the model are integrated of order one. Having stabilized and stationarized the data, we now conduct the co-integration test.

\subsection{Co-integration Test Results}

Since all the variables were integrated of order 1 , we turned to determine the existence of long run equilibrium relationship between the variables, with utmost emphasis on long run relationship between fiscal deficit, financing options and unemployment in Nigeria. Non-stationary time-series can be co-integrated if there are linear combinations of them that are stationary, that is, the combination does not have a stochastic trend. In other words, if two or more I(1) variables are co-integrated, they must obey an equilibrium relationship in the long-run, although they may diverge substantially from that equilibrium in the short run.

The co-integration tests are based on the Johansen and Juselius (1989) test. Tables 4 present the co-integration test results. 
Table 4: Co-integration Results for: UNEP, GDPP, OFDE, DBFD, EBFD, FDI and DCPS

\begin{tabular}{|c|c|c|c|c|}
\hline \multicolumn{5}{|c|}{ Unrestricted Cointegration Rank Test (Trace) } \\
\hline $\begin{array}{l}\text { Hypothesized } \\
\text { No. of CE(s) }\end{array}$ & Eigenvalue & $\begin{array}{l}\text { Trace } \\
\text { Statistic }\end{array}$ & $\begin{array}{l}0.05 \\
\text { Critical Value }\end{array}$ & Prob.** \\
\hline None * & 0.988786 & 442.3844 & 125.6154 & 0.0001 \\
\hline At most $1^{*}$ & 0.885746 & 240.3097 & 95.75366 & 0.0000 \\
\hline At most 2 * & 0.807126 & 142.6897 & 69.81889 & 0.0000 \\
\hline At most 3 * & 0.587258 & 68.63244 & 47.85613 & 0.0002 \\
\hline At most 4 & 0.390412 & 28.81047 & 29.79707 & 0.0646 \\
\hline At most 5 & 0.103621 & 6.536751 & 15.49471 & 0.6320 \\
\hline At most 6 & 0.035234 & 1.614135 & 3.841466 & 0.2039 \\
\hline \multicolumn{5}{|c|}{$\begin{array}{l}\text { Trace test indicates } 4 \text { cointegrating eqn(s) at the } 0.05 \text { level } \\
{ }^{*} \text { denotes rejection of the hypothesis at the } 0.05 \text { level } \\
{ }^{*} \text { MacKinnon-Haug-Michelis (1999) p-values }\end{array}$} \\
\hline \multicolumn{5}{|c|}{ Unrestricted Cointegration Rank Test (Maximum Eigenvalue) } \\
\hline Hypothesized & Figenvalue & $\begin{array}{l}\text { Max-Eigen } \\
\text { Statistic }\end{array}$ & $\begin{array}{l}0.05 \\
\text { Critical Value }\end{array}$ & Prob ** \\
\hline None * & 0.988786 & 202.0747 & 46.23142 & 0.0000 \\
\hline At most 1 * & 0.885746 & 97.61999 & 40.07757 & 0.0000 \\
\hline At most 2 * & 0.807126 & 74.05729 & 33.87687 & 0.0000 \\
\hline At most 3 * & 0.587258 & 39.82197 & 27.58434 & 0.0008 \\
\hline At most 4 * & 0.390412 & 22.27372 & 21.13162 & 0.0344 \\
\hline At most 5 & 0.103621 & 4.922616 & 14.26460 & 0.7516 \\
\hline At most 6 & 0.035234 & 1.614135 & 3.841466 & 0.2039 \\
\hline
\end{tabular}

Source: Author's Computation (2017)

From table 4 above, we also reject the null hypothesis of no co-integration and conclude that there is long run relationship between UNEP, GDPP, OFDE, DBFD, EBFD, FDI and DCPS variables. That is, the variables are cointegrated at $5 \%$ level of significance.

\subsection{VAR Lag Order Selection}

The first step in model building, impulse response analysis and decomposition of the forecast error variance is the selection of the lag order. In this study we use some commonly used lag-order selection criteria to choose the lag order, such as the "Akaike information criterion (AIC)", "Schwartz criterion (SC)", "Hannam-Quinn criterion (HQC)" and "final prediction error (FPE)" to determine the optimum lag and then analyze the residuals.

Table 5: Optimum Lag Test

\begin{tabular}{|l|l|}
\hline AIC & 2 \\
\hline SC & 2 \\
\hline HQC & 2 \\
\hline FPE & 2 \\
\hline \multicolumn{2}{|c|}{ Source: Author's Computation (2017) }
\end{tabular}


Table 5 shows that lag 2 is chosen as the optimum lag in the specification of VAR model on the relationship between fiscal deficit and macroeconomic performance in Nigeria between 1970 and 2016. Thus, we now estimate and analyze the VAR, impulse response and decomposition of the forecast error variance.

\subsection{Impulse Response Analysis and Variance Decomposition}

Since the long-run relationship has been established amongst the variables in the five models, their dynamic properties are further supplemented by the impulse response analysis and forecast error variance decomposition. The first difference of the series can be estimated by inverting the VAR into a moving average representation after which the impulse response as well as the variance decomposition can be estimated.

Table 6: Impulse Response Function for: UNEP = f(GDPP, OFDE, DBFD, EBFD, FDI, DCPS)

\begin{tabular}{|l|l|l|l|l|l|l|l|}
\hline $\begin{array}{l}\text { Perio } \\
\mathrm{d}\end{array}$ & UNEP & GDPP & OFDE & DBFD & EBFD & FDI & DCPS \\
\hline 1 & 1.705403 & 0.000000 & 0.000000 & 0.000000 & 0.000000 & 0.000000 & 0.000000 \\
\hline 2 & 0.612512 & 1.067145 & -1.747566 & 0.298126 & 0.490397 & 0.865526 & 0.047590 \\
\hline 3 & -0.053310 & 0.910315 & -2.470381 & 0.888774 & 0.650696 & 0.495865 & -0.237004 \\
\hline 4 & -1.222436 & 0.453381 & -0.231489 & 0.778069 & 0.417985 & 0.297967 & -0.102200 \\
\hline 5 & -0.851169 & -0.073775 & 1.038017 & 0.670881 & 0.001049 & 0.427804 & -0.068688 \\
\hline 6 & -0.045190 & -0.608592 & 1.310638 & 0.599288 & -0.223396 & -0.249771 & -0.129198 \\
\hline 7 & 0.647996 & -0.066951 & 0.105622 & 0.813721 & -0.296176 & 0.240023 & -0.021614 \\
\hline 8 & 0.767461 & 0.221165 & -1.462939 & 0.313406 & -0.214381 & 0.388056 & -0.084562 \\
\hline 9 & -0.048077 & 0.666082 & -1.776491 & 0.569189 & 0.810974 & 0.463334 & -0.062997 \\
\hline 10 & -0.380120 & 0.400463 & -0.968337 & 0.905990 & 1.134316 & 0.573937 & -0.059481 \\
\hline
\end{tabular}

Source: Author's Computation (2017)

Table 6 (Unemployment Rate (UNEP) model) present the results of the impulse response function for unemployment. From table 6 above, the response of Unemployment Rate (UNEP) to one standard innovation in GDP per Capita (GDPP) is all positive at each time responsive period in the long-run except in the $5^{\text {th }}, 6^{\text {th }}$ and $7^{\text {th }}$ periods. This implies that GDPP on the average has a positive relationship with UNEP in the long-run as shown in figure 1 below.

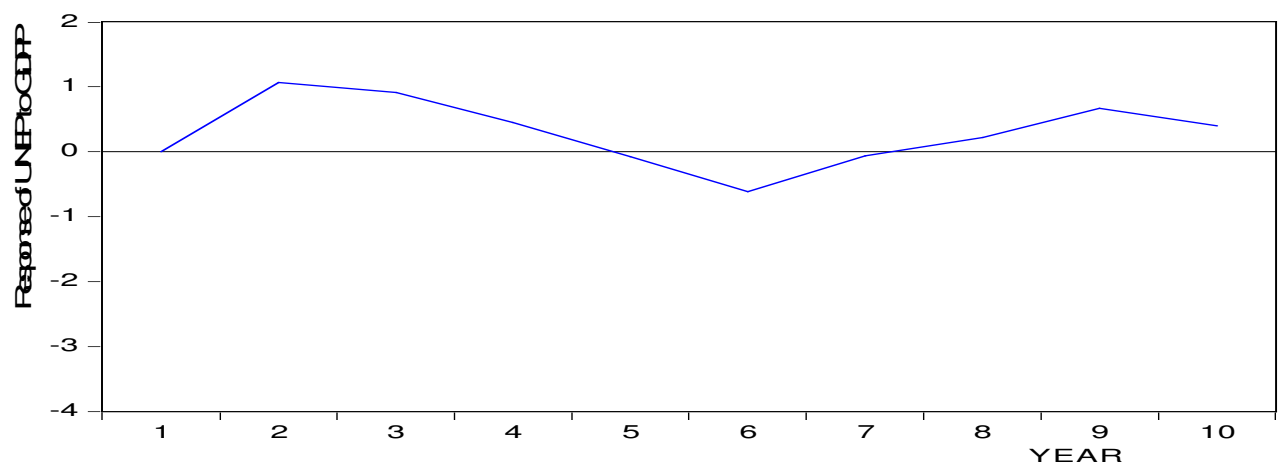

Figure 1: Response of UNEP to GDPP

The response of Unemployment Rate (UNEP) to one standard innovation in the overall fiscal deficit (OFDE) is all negative at each time responsive period in the long-run except in the $5^{\text {th }}, 6^{\text {th }}$ and $7^{\text {th }}$ periods. This implies that UNEP has a negative relationship with OFDE in the long-run as shown in figure 2 below. 


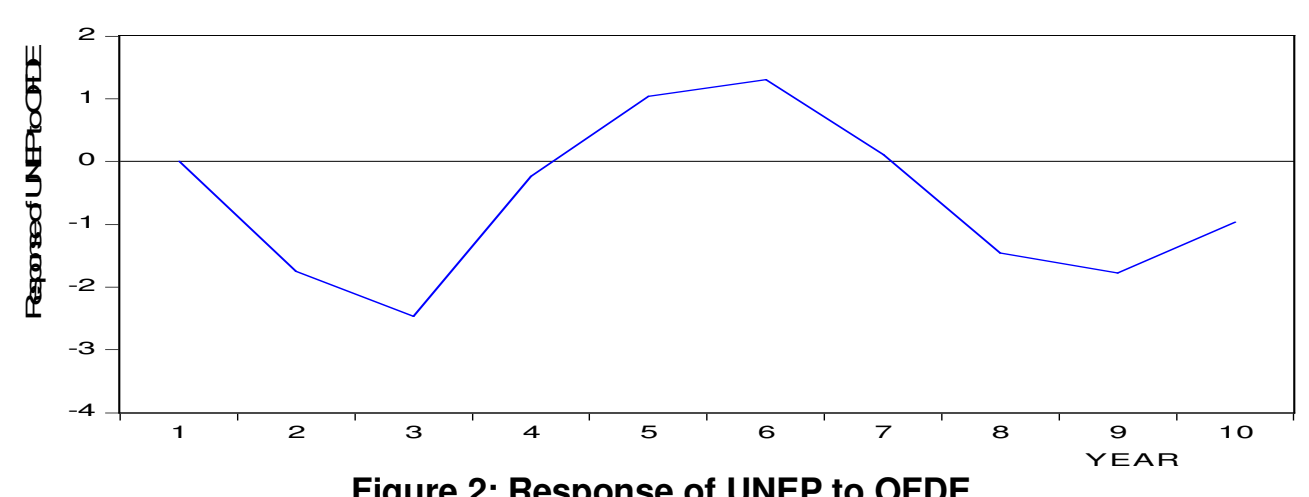

Figure 2: Response of UNEP to OFDE

The response of Unemployment Rate (UNEP) to one standard innovation in the size of overall fiscal deficit financed by domestic borrowing (DBFD) is all positive at each time responsive period in the long-run. This implies that DBFD has a negative relationship with UNEP in the long-run as shown figure 3 below.

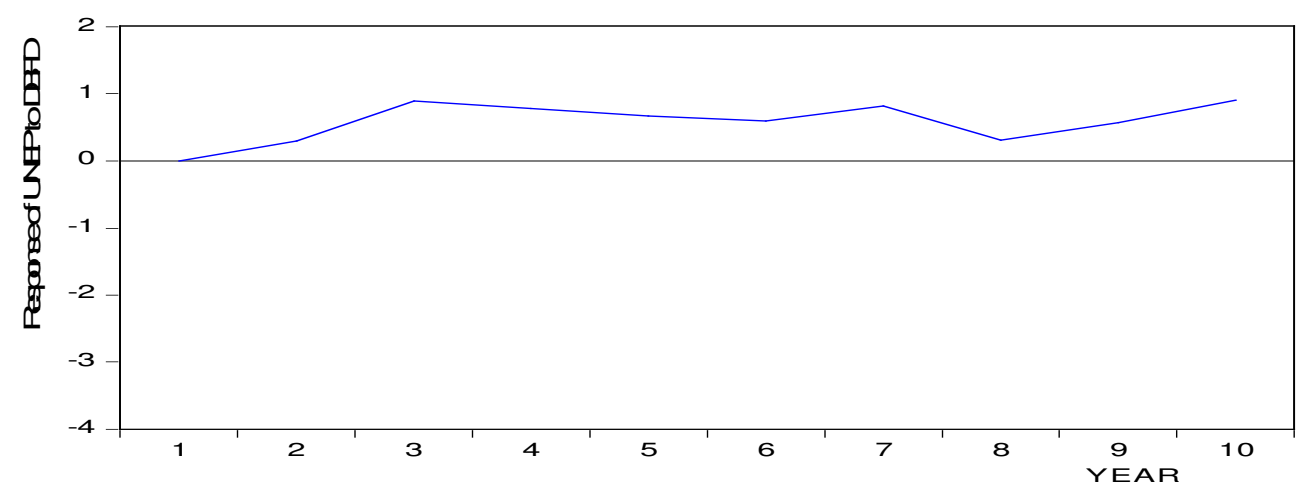

Figure 3: Response of UNEP to DBFD

Table 6 above, also shows that the response of Unemployment Rate (UNEP) to one standard innovation in the size of fiscal deficit financed by external borrowing (EBFD) is all positive at each time responsive period in the long-run except in the $6^{\text {th }}, 7^{\text {th }}$ and $8^{\text {th }}$ periods. This implies that EBFD on the average has a positive relationship with UNEP in the long-run as shown in figure 4 below.

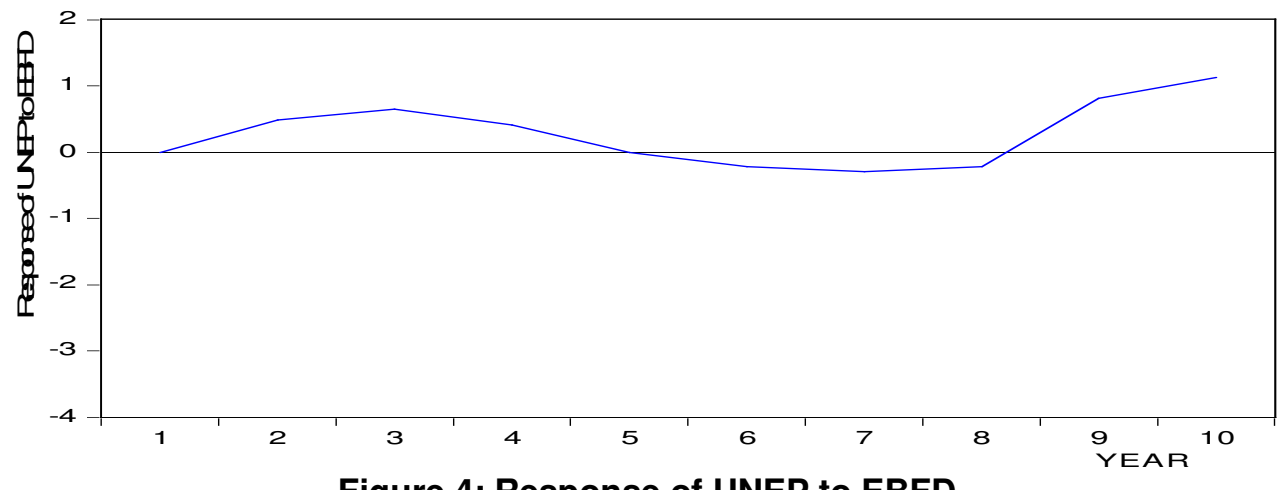

Figure 4: Response of UNEP to EBFD

The response of Unemployment Rate (UNEP) to one standard innovation in Foreign Direct Investment (FDI) is all positive at each time responsive period in the long-run except in the $6^{\text {th }}$ period. This implies that UNEP has a positive relationship with FDI in the long-run as shown in figure 4 below. 


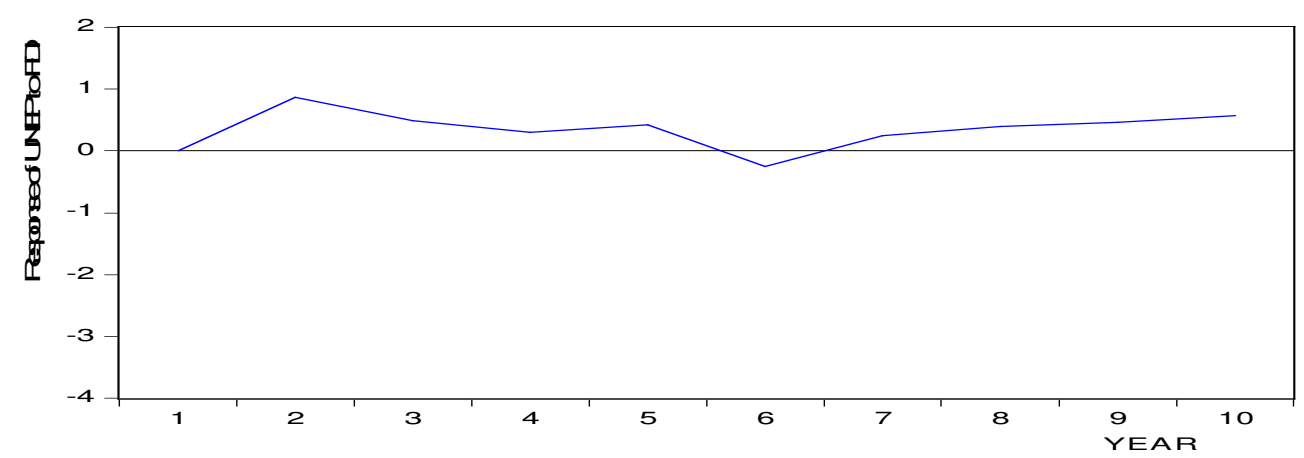

Figure 5: Response of UNEP to FDI

The response of Unemployment Rate (UNEP) to one standard innovation in Domestic Private Sector Credit (DCPS) is all negative at each time responsive period in the long-run. This implies that UNEP has a negative relationship with DCPS in the long-run as shown figure 6 below.

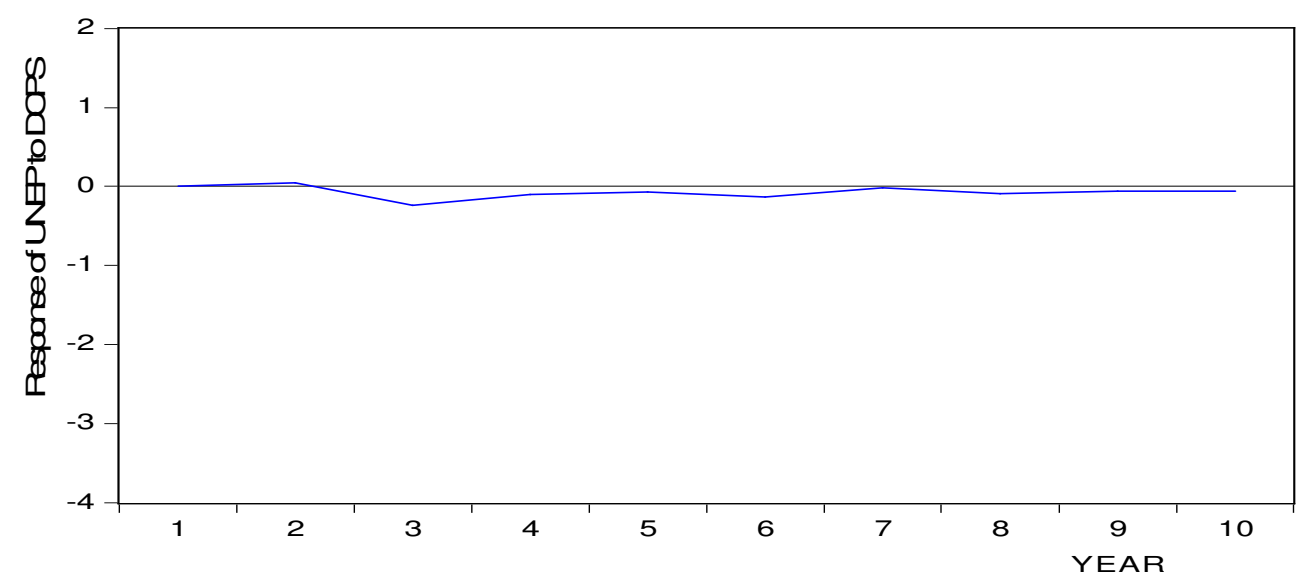

Figure 6: Response of UNEP to DCPS

\subsection{Forecast Error Variance Decomposition (FEVD) Analysis}

The forecast error variance decomposition analysis is presented in tables 7 below. It presents a fraction of the forecast error variance decomposition for each variable in the unemployment model that is attributed to its own innovations and to innovations in other variables. The variance decomposition was estimated so as to see the forecast error components of each of the variables originating from shocks in the system. The ordering of the variables in the variance decomposition is vital and this is stated in tables 7 below over the same forecasting horizon for a period of ten (10) years. 
Table 7: Forecast Error Variance Decomposition for Model Four: UNEP = f(GDPP, OFDE, DBFD, EBFD, FDI, DCPS)

\begin{tabular}{|l|l|l|l|l|l|l|l|l|}
\hline $\begin{array}{l}\text { Perio } \\
\mathrm{d}\end{array}$ & S.E. & UNEP & GDPP & OFDE & DBFD & EBFD & FDI & DCPS \\
\hline \hline 1 & 1.70540 & 100.000 & 0.00000 & 0.00000 & 0.00000 & 0.00000 & 0.00000 & 0.00000 \\
& 3 & 0 & 0 & 0 & 0 & 0 & 0 & 0 \\
\hline 2 & 2.92525 & 38.3723 & 13.3081 & 35.6894 & 1.03865 & 2.81039 & 8.75452 & 0.02646 \\
& 6 & 7 & 8 & 0 & 7 & 7 & 2 & 6 \\
\hline 3 & 4.12393 & 19.3241 & 11.5687 & 53.8418 & 5.16733 & 3.90370 & 5.85070 & 0.34360 \\
& 0 & 1 & 3 & 1 & 8 & 2 & 3 & 2 \\
\hline 4 & 4.43166 & 24.3424 & 11.0645 & 46.8968 & 7.55711 & 4.26997 & 5.51844 & 0.35072 \\
& 1 & 3 & 0 & 1 & 8 & 0 & 3 & 2 \\
\hline 5 & 4.69945 & 24.9277 & 9.86408 & 46.5832 & 8.75836 & 3.79720 & 5.73614 & 0.33325 \\
& 2 & 3 & 8 & 3 & 2 & 6 & 0 & 4 \\
\hline 6 & 4.96620 & 22.3300 & 10.3346 & 48.6782 & 9.29895 & 3.60258 & 5.38942 & 0.36609 \\
& 4 & 2 & 5 & 7 & 3 & 9 & 5 & 5 \\
\hline 7 & 5.08985 & 22.8790 & 9.85590 & 46.3848 & 11.4084 & 3.76827 & 5.35312 & 0.35032 \\
& 8 & 3 & 7 & 5 & 9 & 2 & 1 & 6 \\
\hline 8 & 5.38392 & 22.4799 & 8.97740 & 48.8395 & 10.5351 & 3.52642 & 5.30382 & 0.33777 \\
& 8 & 4 & 0 & 2 & 2 & 1 & 4 & 1 \\
\hline 9 & 5.81282 & 19.2918 & 9.01455 & 51.2383 & 9.99665 & 4.97167 & 5.18537 & 0.30151 \\
& 0 & 5 & 1 & 8 & 7 & 0 & 8 & 1 \\
\hline 10 & 6.12142 & 17.7813 & 8.55651 & 48.7047 & 11.2046 & 7.91672 & 5.55479 & 0.28131 \\
& 5 & 2 & 9 & 0 & 1 & 8 & 6 & 8 \\
\hline
\end{tabular}

Source: Author's Computation (2017)

Table 7 present the results of the variance decomposition for unemployment. It shows that 100 percent of variance in Unemployment Rate (UNEP) in period 1 is explained by the shock from the variable itself. This implies that there was no shock from other variables. In period 2, 38 percent of the variance in Unemployment Rate (UNEP) was explained by the shock from the variable itself; 13.30 percent from GDPP; 35.68 percent from fiscal deficit (OFDE); 1.03 percent from the size of fiscal deficit financed by domestic borrowing (DBFD); 2.81 percent from the size of fiscal deficit financed by external borrowing (EBFD); 8.75 percent from Foreign Direct Investment (FDI); and 0.02 percent from Domestic Private Sector Credit (DCPS).

Inferences from period 2 to 10 shows that apart from the variance due to the shock from the variance of Unemployment Rate (UNEP) itself, overall fiscal deficit (OFDE) is the variable with the highest percentage of induced variance on Unemployment Rate (UNEP) of about 48 percent while GDPP, DBFD, EBFD, FDI and DCPS induce 8 percent, 11 percent, 7 percent, 5 percent and 0.28 percent respectively.

\subsection{VAR Granger Causality Results}

The results of the VAR granger causality tests of the variables in the model are presented in Tables 8 below. 
Table 8: VAR Granger Causality Tests Result for: UNEP, GDPP, OFDE, DBFD, EBFD, FDI, DCPS

\begin{tabular}{|c|c|c|c|c|c|c|c|c|}
\hline \multirow{2}{*}{$\begin{array}{l}\text { Depende } \\
\text { nt } \\
\text { Variables }\end{array}$} & \multicolumn{7}{|c|}{$X^{2}$ Statistics [p-values] } & \multirow[b]{2}{*}{$\begin{array}{l}\text { Joint } \\
\text { Causality }\end{array}$} \\
\hline & UNEP & GDPP & OFDE & DBFD & EBFD & FDI & DCPS & \\
\hline UNEP & - & $\begin{array}{l}15.3534 \\
{[0.0005]}\end{array}$ & $\begin{array}{c}30.5590 \\
{[0.0000]}\end{array}$ & $\begin{array}{l}2.05576 \\
{[0.3578]}\end{array}$ & $\begin{array}{l}22.0174 \\
{[0.0000]}\end{array}$ & $\begin{array}{l}45.4653 \\
{[0.0000]}\end{array}$ & $\begin{array}{l}12.9349 \\
{[0.0016]}\end{array}$ & $\begin{array}{l}115.8992 \\
{[0.0000]}\end{array}$ \\
\hline GDPP & $\begin{array}{l}2.5117 \\
{[0.2848]}\end{array}$ & - & $\begin{array}{l}6.6771 \\
{[0.0355]}\end{array}$ & $\begin{array}{l}0.9124 \\
{[0.6337]}\end{array}$ & $\begin{array}{l}3.62435 \\
{[0.1633]}\end{array}$ & $\begin{array}{l}1.0819 \\
{[0.5822]}\end{array}$ & $\begin{array}{l}2.6876 \\
{[0.2608]}\end{array}$ & $\begin{array}{r}19.0742 \\
{[0.0868]}\end{array}$ \\
\hline OFDE & $\begin{array}{l}13.5576 \\
{[0.0011]}\end{array}$ & $\begin{array}{l}0.2471 \\
{[0.8838]}\end{array}$ & - & $\begin{array}{l}6.4986 \\
{[0.0388]}\end{array}$ & $\begin{array}{l}6.5558 \\
{[0.0377]}\end{array}$ & $\begin{array}{l}3.5460 \\
{[0.1698]}\end{array}$ & $\begin{array}{l}15.8642 \\
{[0.0004]}\end{array}$ & $\begin{array}{l}77.2340 \\
{[0.0000]}\end{array}$ \\
\hline DBFD & $\begin{array}{l}6.8357 \\
{[0.0328]}\end{array}$ & $\begin{array}{l}0.0915 \\
{[0.9553]}\end{array}$ & $\begin{array}{c}10.6865 \\
{[0.0048]}\end{array}$ & - & $\begin{array}{l}69.2093 \\
{[0.0000]}\end{array}$ & $\begin{array}{l}8.51387 \\
{[0.0142]}\end{array}$ & $\begin{array}{l}17.1107 \\
{[0.0002]}\end{array}$ & $\begin{array}{l}128.3243 \\
{[0.0000]}\end{array}$ \\
\hline EBFD & $\begin{array}{l}0.06737 \\
{[0.9669]}\end{array}$ & $\begin{array}{l}3.4341 \\
{[0.1796]}\end{array}$ & $\begin{array}{l}0.4328 \\
{[0.8054]}\end{array}$ & $\begin{array}{l}1.7029 \\
{[0.4268]}\end{array}$ & - & $\begin{array}{l}0.4144 \\
{[0.8128]}\end{array}$ & $\begin{array}{l}0.3324 \\
{[0.8469]}\end{array}$ & $\begin{array}{l}12.4285 \\
{[0.4119]}\end{array}$ \\
\hline FDI & $\begin{array}{l}22.6778 \\
{[0.0000]}\end{array}$ & $\begin{array}{l}5.2988 \\
{[0.0707]}\end{array}$ & $\begin{array}{c}6.2913 \\
{[0.0430]}\end{array}$ & $\begin{array}{l}29.8429 \\
{[0.0000]}\end{array}$ & $\begin{array}{l}17.8735 \\
{[0.0001]}\end{array}$ & - & $\begin{array}{l}30.5286 \\
{[0.0000]}\end{array}$ & $\begin{array}{l}85.4289 \\
{[0.0000]}\end{array}$ \\
\hline DCPS & $\begin{array}{l}1.9573 \\
{[0.3758]}\end{array}$ & $\begin{array}{l}7.6097 \\
{[0.0223]}\end{array}$ & $\begin{array}{l}2.1825 \\
{[0.3358]}\end{array}$ & $\begin{array}{l}112.113 \\
6 \\
{[0.0000]}\end{array}$ & $\begin{array}{l}21.0395 \\
{[0.0000]}\end{array}$ & $\begin{array}{l}97.7616 \\
{[0.0000]}\end{array}$ & - & $\begin{array}{l}376.3756 \\
{[0.0000]}\end{array}$ \\
\hline
\end{tabular}

Note: The figures in parenthesis are the probability values

Source: Author's Computation (2017)

Table 8 above present the VAR granger causality tests result for model four, that is, unemployment model. From the result, we found that there is a joint granger causality running from GDPP, OFDE, DBFD, EBFD, FDI and DCPS to UNEP; there is no joint granger causality running from UNEP, OFDE, DBFD, EBFD, FDI and DCPS to GDPP and there is a joint granger causality running from UNEP, GDPP, DBFD, EBFD, FDI and DCPS to OFDE. Furthermore, we found that there is a joint granger causality running from UNEP, GDPP, OFDE, EBFD, FDI and DCPS to DBFD while there is no joint granger causality running from UNEP, GDPP, OFDE, DBFD, FDI and DCPS to EBFD. Again, the study also reveals that there is a joint granger causality running from UNEP, GDPP, OFDE, DBFD, EBFD and DCPS to FDI and there is also a joint granger causality running from UNEP, GDPP, OFDE, DBFD, EBFD and FDI to DCPS.

\subsection{Summary and Discussion of Findings}

1. The study found a cointegrating (long run) relationships between fiscal deficits; financing options vis-a-viz domestic and external borrowing and unemployment rate in Nigeria.

2. The relationship between unemployment and overall fiscal deficit (OFDE) was found to be negative. However, the study found positive relationships between unemployment, the size of fiscal deficit financed by domestic borrowing (DBFD) and the size of fiscal deficit financed by external borrowing (EBFD) respectively, in the longrun, in Nigeria.

3. Overall fiscal deficits (OFDE) and the size of fiscal deficits financed by domestic borrowing (DBFD) were the main shocks causing the variation in unemployment rate (UNEP) in Nigeria.

In summary, the study reveals that among the endogenous variables, the shocks due to overall fiscal deficits (OFDE) contributes more to variance in unemployment rate (UNEP) with an average of about 49 percent followed by the size of fiscal deficits financed by domestic borrowing (DBFD) with an average of about 11 percent with the period under review. This implies that overall fiscal deficits (OFDE) and the size of fiscal deficits financed by domestic borrowing (DBFD) are the main shocks causing the variation in unemployment rate (UNEP) in Nigeria within the period of study. 
Prolonged fiscal deficits in Nigeria have resulted into mounting public debt and debt overhang in Nigeria. Humongous sums are being budgeted for debt services, which have hampered economic progress, as the debt burden has become an impediment to undertaking new capital projects with positive linkages to stimulate employment and growth in Nigeria. Our finding corroborates with previous studies such as Wosowei (2013) and Eze and Nwambeke (2015). These scholars have found that increased public borrowing like domestic borrowing to financed fiscal deficit has cause the high unemployment rate in Nigeria. They also opined that rapid increasing debt service obligations constitute an obstacle to the implementation of new development oriented projects therefore worsening unemployment situation since a proportion of revenue for this purpose is set aside for servicing previous debts.

\subsection{SUMMARY, CONCLUSION AND RECOMMENDATIONS}

This study examined the relationships between fiscal deficits; financing options vis-a-viz domestic and external borrowing and unemployment in Nigeria from 1970 to 2016. The study adopted a four-stage methodology to investigate these relationships as well as the magnitude influences on unemployment. First the stationary status of the data series was examined using Augmented Dickey Fuller unit root test. This was followed by Johansen cointegration test. The third stage was the VAR method and the fourth stage was VAR granger causality test.

Consequent upon the findings of this study, we, therefore, concludes that fiscal deficits have chiefly contributed to the worsening of unemployment in Nigeria. Evidence from Nigeria does not support the Keynesian view that fiscal deficits have the stimulating ability to create employment. This conclusion is empirically justified, given that fiscal deficits have not stimulated employment and economic growth in Nigeria. These findings may not be unconnected with the nature of Nigeria's fiscal operation, which is characterized by fiscal indiscipline, wastes, mounting/unsustainable debt burden (principal and interest servicing), poor budget processes (preparation, execution and monitoring) and systemic corruption.

The study, therefore, recommends moderation in fiscal deficits regime. The negative macroeconomic effects of unrestricted fiscal deficits regime as in the case of Nigeria, far outweigh any gain these deficits can produce. Government should, therefore, moderate the level of fiscal deficits as well as moderate the financing of deficits through public borrowing especially the domestic component, as it has more negative magnitude influence in worsening unemployment in Nigeria. Secondly, government should adopt fiscal adjustment mechanism that increases revenue through improved taxes rather than borrowing to finance deficit and dependence on crude oil. With appropriate adjustments and reforms in place, Nigeria has enormous capacity to increase revenue from taxes to finance her fiscal expenditures. Nigeria's tax to GDP ratio that is currently at about 6 percent indicates huge underutilized capacity to generate revenue through taxes. This would reduce Nigeria's current debt burden. The present utilization of approximately 25 percent of the annual budget for debt servicing is anti-development and unsustainable. If borrowing is inevitable, external borrowing financing sources should be the preferred choice. This financing option is cheaper in terms of interest services and longer tenors compare to domestic borrowing sources that not only crowds private investment, but also in terms of higher interest rate and shorter tenors.

\section{REFERENCES}

Ali, D.U and U. G Ahmad (2014). Effect of fiscal deficit and Government expenditure on economic growth in Nigeria. JORIND 12 (1); www.transcampus.org/journals

Antonio, F. and Llian, M (1998). The effects of fiscal policy on consumption and employment: theory and evidence. Correspondence of the European Summer Symposium on International Macroeconomics, Tarragona.

Anyanwu, J. C. (1995). Do fiscal deficits produce high interest rates? The Case of Nigeria, Ghana and the Gambia. CBN Economic and Financial Review, Vol. 36, No. 1,

Arewa A. \& Nwakahma C. (2013). Macroeconomic variables and the dynamic effect of public expenditure: Long-term trend analysis in Nigeria. Journal of Knowledge Management, Economics and Information Technology.

Central Bank of Nigeria. Annual Report and Statement of Account. Various Issues; Abuja Nigeria

Central Bank of Nigeria (2009). Statistical Bulletin: Central Bank of Nigeria. Abuja.

Central Bank of Nigeria (2015). Statistical Bulletin: Central Bank of Nigeria. Abuja.

Debt Management Office (2010). Federal Government domestic debt outstanding by instruments; June, Abuja Nigeria

Debt Management Office (2017). Federal Government Public debt outstanding; December, 2016, Abuja Nigeria

Dewett, K.K. (2009). Modern economics theory (Revise edition). New Delli S. Chand \& Company Ltd.

Eze, O. R., and Nwambeke, G. C. (2015). Effect of deficit financing on unemployment rate in Nigeria: An error correction model. International Journal of Small Business and Entrepreneurship, 3(7), 28-46. 
Johansen, S. (1995). Likelihood-based Inference in Co-integrated Vector Autoregressive Models. Oxford, Oxford University Press.

Keynes, J.M. (1936). The General Theory of Employment, Interest Rate and Money: London: Macmillian.

Michele, C. (2005). Government employment and the dynamic effects of fiscal policy shocks. Working Paper Series 2005-16. Federal Reserve Bank of Sanfransisco.

Mohanty R. K (2012). Fiscal deficit-economic growth nexus in India: A Co-integration analysis. Centre for Economic Studies \& Planning, School of Social Sciences, Jawaharlal Nehru University; New Delhi- 110067

Nwankwo, A. (March 20, 2017). External debt servicing gulps $\$ 1.62 \mathrm{bn}$ in five years. Punch Newspapers. Retrieved from http://punchng.com

Nwankwo, A. (Februaray 4, 2017). Nigeria spends N1.1trn on debt servicing in 9 months. Punch Newspapers. Retrieved from http://punchng.com

Obayori, J.B (2016). Fiscal policy and unemployment in Nigeria. The International Journal of Social Sciences and Humanities, 4(1): 142-150.

Oluba, M.N. (2008). How years of fiscal deficits emasculated the Nigerian economy. Economic Reflections, 1(5): 610.

Omitogun O. and Tajudeen A. (2007). Fiscal Policy and Nigerian economic growth. Journal of Research in national development Vol.5: 22-26

Saleh, A. S. (2003). The Budget deficit and economic performance: A Survey. University of Wollongong, Economic Working Paper Series.

Sims, C. (1980). Macroeconomics and reality. Econometrica, 48(1): 1-48

Tobin, J. (1982). Money and finance in the macroeconomic process. Cowless Foundation Discussion Paper, 613R

Wosowei E. (2013). Fiscal deficits and macroeconomic aggregates in Nigeria. Kuwait Chapter of Arabian Journal of Business and Management Review. Vol. 2, No.9; May, 2013

Cite this Article: Nwaeze NC, Kalu IE, Tamuno SO (2017). Does Fiscal Deficit Stimulate Employment? Evidence from Nigeria's Experience: VAR Approach. Greener Journal of Economics and Accountancy, 6(3): 065-081, http://doi.org/10.15580/GJEA.2017.3.112017169 